\title{
Tonic or Toxin? The State, Neopatrimonialism, and Anticorruption Efforts in Nigeria
}

\author{
Osumah Oarhe*
}

\begin{abstract}
Nigeria is mired in corruption although it has many anticorruption laws, commissions, and agencies. This article, based on secondary data sources, examines the effect of the state and neopatrimonialism on anticorruption efforts in Nigeria. It argues that the contradictions in the character of the Nigerian state and the logic of neopatrimonialism hinder Nigeria's anticorruption efforts, and recommends a redesigning of the state and reorientation of the mindsets of Nigerians to better enable anticorruption efforts to succeed.
\end{abstract}

Keywords: the Nigerian state, neopatrimonialism, anticorruption

\section{INTRODUCTION}

There is a preponderant view among scholars, individuals, professionals, and business interests that corruption is responsible for an array of socioeconomic development failures, political instability, infrastructure decay, institutional fragility, low investment, and poor democratic consolidation in Nigeria as in many other postcolonial African states (Szeftel, 2000a, 2000b). Corruption has been characterized as a dangerous social malaise that has eaten deep into the fabric of the nation (Bello-Imam, 2005). Nigeria has been consistently ranked by Transparency International as one of the most corrupt nations in the world (Goodling, 2003). Corruption makes headlines and has become a recurrent issue in everyday discourse (Smith, 2007).

Since the end of the colonial era, successive governments in Nigeria have expressed great concern about anticorruption. This is reflected in the promises in their inaugural broadcasts, speeches, and programs to tackle corruption, and in their genuine or perfunctory attempts to implement anticorruption policy. This represents a consensus that corruption undermines effective governance, development reforms, and democracy.

\footnotetext{
* Dr. Osumah Oarhe is a Lecturer in the Department of Public Administration, Ambrose Alli University, Ekpoma, Nigeria. E-mail: osumahoarhe@yahoo.com.
}

Manuscript received January 26, 2013; out for review February 1, 2013; review completed April 5; accepted April 16, 2013.

The Korean Journal of Policy Studies, Vol. 28, No. 1 (2013), pp. 111-134.

(C) 2013 by the GSPA, Seoul National University 
This article explores the character of the Nigerian state and neopatrimonialism in Nigeria and whether they have helped or hindered the country's anticorruption efforts.

\section{THE NIGERIAN STATE}

Scholars have offered competing conceptions of the nature of modern states. Weber's conception, one of the most popular, characterizes states as nation-states defined by political apparatuses, distinct from both ruler and ruled, with supreme jurisdiction over a demarcated territorial arena, backed by a claim to monopoly of coercive power, and enjoying a minimum level of support or loyalty from their citizens (Held, 1992). In this approach, the primary role of the state is to act as a framework of rules, which empowers the people, encourages relations of mutual respect and co-operation among constituent groups, and reduces opportunities for predation and exploitation (Wunsch \& Olowu, 1995). Thus, in analyzing the state, a critical step is to establish the extent to which the ruler of the state is separated from its established administrative institutions. Also central is the extent to which the state legitimately secures the loyalty and obedience of its citizenry. The legitimacy of the state is related to the extent to which it fulfills its obligation to meet the welfare needs of its citizenry.

This conception of the modern state has generated a lot of debate. Weber's definition of the state - as an institutional site that permits various engagements in a society to take place in a sustained, predictable, and legal fashion-is useful to an understanding of issues in Nigeria and elsewhere.

The Nigerian state, like a number of African states, was formed by the British imperial administration, which forcibly lumped together in a single political entity hitherto autonomous empires and kingdoms with diverse political histories. Nigeria was also ruled by force with little effort to foster a spirit of nationalism among the constituent communities. This resulted in a tenuous sense of nationalism in which the state has been variously characterized as "colonial bequeathal" (Aghemelo \& Osumah, 2009 ), "mere British imposition and heritage (Awolowo, 1968)", "mere geographical expression" (Awolowo, 1947) and "the mistake of 1914" (Coleman, 1958). The tenuous sense of nationalism or citizenship in Nigeria has been graphically captured thus:

Beyond phrase-mongering, there are no citizens in Nigeria, only citizens of Nigeria. . . . That is, Nigerian citizenship is merely geographical, it is without moral-ideological content. . . . Part of what typifies citizenship, especially in the modern state, is the de-emphasizing of geography and other natural facts in its composition. . . . The freedom to locate anywhere within the boundaries of the relevant geo-polity is non-existent in Nigeria. (cited in Ogundiya, 2009, p. 285) 
In addition to the manner of the formation of the Nigerian state, the weak senseof nationalism was reinforced by widespread politicization of the local identity by indigenous nationalists in rallying political support for the anticolonial struggle (Mamdani, 1996; Ogbeide, 2003). During that period, the local populace was promised better life at independence without consideration of the capital base of the state. Thus, at independence, the emerging custodians of the state encountered intense pressure from aggressive and demanding constituents (Turok, 1987).

Like a number of postcolonial African states, Nigeria is highly centralized, with authority, responsibility, and resources concentrated in the central government. Formal institutions of government are centrally controlled, while charitable association capacity for collective action has been reduced. This presupposes that the postcolonial Nigerian state is omnipresent and bloated and intervenes in both private and public sectors. Thus, it disables the formal and benevolent organizations from engaging in collective responsibility. The authority, responsibility, and resources of the state are disproportionately distributed. This has been described as personal rule. It does not permit, tolerate, or institutionalize opposition. It often pre-empts negotiation with the critical elements of the society. Although the state wields so much power and has so many resources, it is often too weak to compel citizens to comply with its orders-a situation that has been called the disengaged or soft state (Wunsch \& Olowu, 1995).

The intrusiveness of the Nigerian state, combined with its reliance on oil rents derived from external sources rather than direct taxes derived from domestic sources, undermines incentives for productive investment and accentuates distributive concerns (sometimes referred to as a national cake-sharing mentality). This situation, combined with the inability of the Nigerian state to effectively utilize its enormous power and resources to meet its sovereign obligations and fulfill the needs and aspirations of citizens, creates a situation in which various stakeholders, individuals and groups, pursue selfish interests rather than the collective welfare. This undermines the spirit of cooperation, nationalism, and the ability to act in concert to realize common goals (Lewis, 2004).

Such a situation leads to use of unorthodox methods of competition, patrimonial rule, and compromise of mechanisms of accountability. Centralized and monopolistic state institutions are also vulnerable to displacement of goals, personal ambition, incomplete control by political leaders, pressures and ambiguities, moral hazards, and opportunism. The institutions of the Nigerian state are fairly weak in mobilizing and coordinating capacities for the pursuit of the collective will. Also, the intrusiveness of the Nigerian state combined with its weak capacity results in economic disequilibrium, macroeconomic volatility, and non-populist and bourgeois control of state power, as well as political powerlessness, marginalization, and exclusion of the majority from 
the political mainstream and better welfare (Ojo, 1995). Thus, in Nigeria, like in many centralized postcolonial African states, only a small elite benefits while most people suffer economically (Wunsch \& Olowu, 1995).

Although the postcolonial state has a towering presence and monopolistic bureaucratic control, it has been characterized as weak (Jackson \& Rosberg, 1982), fragile (Osaghae, 2007), lame or crippled (Callaghy, 1987; Osaghae, 2002), failing (Wunsch \& Olowu, 1995), collapsing (Zartman, 1995), shadow (Reno, 2000), and irrelevant (Ihonvbere, 1994). The pathologies of the state are reflected by lack of capacity for resource allocation, ineffectiveness of administrative agencies, widespread and extreme corruption, politicization of political authority, constitutional erosion, a legitimacy crisis, and increasing public distrust. These ills associated with the postcolonial state undermine institutional integrity.

\section{NEOPATRIMONIALISM}

Neopatrimonialism is a modern form of the traditional patrimonial system of rule, as a mixed system that includes elements of both patrimonialism and legal-rational rule. A patrimonial system is based on informal or personal relationships; in it, state authorities do not distinguish between private and public interests. A neopatrimonial system has an impersonal power structure that theoretically does separate private and public interests, but in actuality there is no clear distinction. Neopatrimonialism is thus a mixed system with two institutionalized reference points, formal and informal (Erdmann \& Engel, 2007).

A core component of neopatrimonialism is clientelism. Political clientelism is a reciprocal relationship involving distribution of resources or engagement of services between patrons and their clients. Clients rally political support for their patron in the form of votes, and in return the patron distributes resources or services to themusually public goods and resources rather than private possessions (Erdmann \& Engel, 2007). Clientelism can be characterized as a strategy to secure protection and help in achieving objectives in an insecure and unpredictable social, political, and institutional context. Though clientelism seems to accommodate the voice of the masses, it does not guarantee equal access to public goods and services. In fact, it helps perpetuate the insecurity of state institutions and politics because of the distribution and exchanges of services in line with the codified laws (Szeftel, 2000b).

Another distinctive component of a neopatrimonial system is patronage politics, characterized by Joseph $(1987,1995)$ as prebendalism. This is the politicization of enclaves by the elite to become or remain relevant in the political chessboard of a 
plural society. The incumbents of political power appropriate and distribute public resources to serve people in their regions, constituencies, and ethnic enclaves. An equally significant component of the neopatrimonial system is personalization of power and monopolistic rule, with high concentration of power in the chief executive. Personal rule results in poor judgment, disregard for separation of powers, contempt for other institutions and active subversion of the constitution and the rule of law (Rotberg, 2004).

Neopatrimonialism is not unique to any one part of the world, but it is regarded as a dominant feature of the developing countries of Africa, Latin America, the Middle East, southern Europe, and the former communist bloc (Bratton \& Van de Walle, 1997). The dynamics and prevalence of neopatrimonialism in Africa at the end of colonialism has been well documented (Boas, 2001; deGrassi, 2008; Erdmann \& Engel, 2006; Hansen, 2003; Mamdani, 1996). The foundation of neopatrimonialism in Africa derived from the experiences of colonialism combined with the precolonial style of administration (patrimonialism). The colonial experience resulted in what has been characterized as creative destruction of the bundled processes in the traditional pattern of administration and their supplanting with new formats and organizational institutions unfit and ill adapted to the political realities in Africa (de Oliveira, 2007).

At independence, in the face of a crisis of legitimacy and in the quest for survival, the emerging leaders combined traditional structures with transplanted illiberal democratic structures of colonial administration. For instance, a number of new African leaders sought legitimacy by symbolic references to an imagined African style of rule. For example, Julius Nyerere of Tanzania preferred to be called Mwalimu, the teacher, and Mobutu Sese Seku of Zaire encouraged the press to style him as the guide. Gnassingbe Eyadema of Togo encouraged rumors about his occult powers. Felix HouphouetBoigny of Cote d' Ivoire encouraged la palabre', in which he visited villages and staged dialogues where citizens were encouraged to discuss their problems directly with him (an African mode of political participation and problem-solving). Leaders used state resources and a large amount of patronage to gain the support they could not gain through the ballot box. Political power was personalized rather than institutionalized (Van de Walle, 2001).

The neopatrimonialization of states in Africa by the new custodians of power and authority resulted in its characterization, beginning in the closing decades of the 20th century, as irresponsive (Ojo, 1995), hybrid, transplanted (Dia, 1996; Ekeh, 1975), or an empty shell or rhizome state (Chabal \& Daloz, 1999).

Neopatrimonialism has the capacity of diverting public resources to serve private interests rather than enlightened interests. It is a mechanism which a political elite or political party uses to promote its political ascendancy or retain its relevance. It can 
undermine policy design and implementation and thus contribute to deviation from a policy goal. It can also undermine the culture of productive investment in the society and it celebrates mediocrity.

Neopatrimonial rule engenders a high sense of insecurity, because action by the state is unpredictable for every actor save for the chief executive and his loyalists. In such a situation, every person strives to play safe and not to offend or cross personal interests of the chief executive. This means that state institutions only function in a limited way in the promotion and protection of common interests (Erdmann \& Engel, 2007).

Under neopatrimonial rule, particularistic politics predominate. Formal rules exist side by side with informal rules, which are based on affection, reverence, or fear and sometimes overshadow the formal rules (Erdmann \& Engel, 2007). Informal rules are usually incompatible with efficiency. They facilitate corruption and undermine attempts to improve the fair application of the law. Quite often, public officials play favorites in dealing with their alter egos, professional colleagues, or proximate groups. This undermines the transparency and effectiveness of public and private institutions. As Rose-Ackerman (1999, p. 106) noted, "In societies with embedded interpersonal networks, citizens may care little about market and public sector efficiency. They may view impersonal markets as illegitimate and morally bankrupt." Public officials feel the need to protect their colleagues rather than launch a serious enquiry into apparently corrupt practices.

\section{REQUIREMENTS FOR AN EFFECTIVE ANTICORRUPTION EFFORT}

Anticorruption efforts are based on clearly articulated rules governing official conduct. A number of factors have been identified as critical to an effective anticorruption drive. The first is that it must be inclusive and comprehensive: as much as possible, all stakeholders, both the elite and the ordinary citizens, must be involved. This engenders a greater sense of belonging and ownership for the policy. All stakeholders are affected by corruption and are essentially in the position to take action against it in their everyday lives and to rally support for the anticorruption movement (UNODC, 2003).

Furthermore, it is believed that an effective anticorruption measure must be integrated (UNODC, 2003), addressing as much as possible the range of factors that contribute to corruption. If corruption of public officials is, for instance, ascribed to low social status, poor remuneration, absence of effective law, weak law enforcement agencies, and cultural values, the anticorruption strategy should identify and address all such factors. It is also recognized that the best anticorruption strategies are likely to vary 
from country to country. Broad participation in the development of strategies ensures that the goal and responsibility for its implementation are clearly articulated and established. Strategies need to be long term, involve a wide range of policies, and remain flexible and dynamic; they should involve periodic monitoring and assessment.

Another major requirement for an effective anticorruption strategy is transparency in government. This means that the population should be well informed about the activities of the custodians of state power. This will encourage broad enthusiasm and willingness to participate in the anticorruption movement and can serve as a deterrent to those in government who may be tempted to be corrupt (Stouffer, Opheim, \& Day, 1996). Lack of transparency in an anticorruption drive is likely to result in public ignorance, loss of credibility, and popular perception of it as merely impressionistic. Where transparency does not exist, popular suspicion may be well justified (UNODC, 2003).

Equally identified as core requirement for an effective anticorruption effort is political neutrality in the creation and application of the rules. Political, socioeconomic, or ethnic affiliation should not be considered in the administration of anticorruption rules (UNODC, 2003). Thus, an impartial arbiter is needed who will apply the rules with a reasonable degree of equity and fairness. Selective, partisan, discriminatory, or arbitrary application of the rules is toxic to an anticorruption effort. Where corruption becomes a norm, the popular perception is that the custodians of power use it to reward their followers and homeland (place of origin). A reversal of this attitude and promotion of the belief that any faction that is enriching itself is not acting in the public interest is core to a successful anticorruption drive. When corrupt custodians of state power give preference to members of their own tribe in recruitment for strategic positions and awarding of contracts, in order to remain relevant and to realize their personal interests, an anticorruption drive is undermined.

An effective anticorruption drive also requires that mechanisms be established for people to report corrupt practices-formal recognition of whistle-blowing, existence of institutions, and principles of integrity - and that these mechanisms be safeguarded against abuse, for example false reporting out of malice or to conceal one's own wrongdoing. Thus, the integrity of the police and the courts must be a major aspect of an anticorruption agenda in order to inspire the confidence of the people (Szeftel, 2000b).

In Nigeria, the law enforcement agencies established to combat corruption include the police, National Assembly, Public Account Committee, auditor-general, courts, commissions, Code of Conduct Bureau, and Public Complaints Commission. However, the existence of a legal framework does not guarantee the success of an anticorruption effort. The legal framework must be fully operational. Institutional fragility reflected 
by personal rule, a culture of impunity, and protection of the image of culpable highprofile individuals and their cronies leads to loss of credibility and trust of the people in an anticorruption drive. Another important element is the distinction between petty corruption and more serious corruption with a range of appropriate sanctions (Szeftel, 2000b).

Also a key element is public education, which can increase public awareness of what constitutes corruption, its causes, the harm it causes, and the need to support anticorruption efforts. Anticorruption efforts depend on citizens' preparedness to combat corruption. The support and participation of civil society are vital to monitor anticorruption efforts and to expose and deter corruption. This includes the opportunity to exert political pressure against corruption anywhere it is found, assisting in developing countermeasures and providing objective criteria (UNODC, 2003).

The willingness of citizens to fight corruption depends on the extent to which the state is able to fulfill its obligations to them. Where access to economic opportunities is limited or the state does not discharge its core functions effectively, people have to resort to alternative means of survival. In a state where access to political office becomes the surest avenue to accumulation of wealth, or the custodian of state power becomes very powerful and entitled to many perquisites, anticorruption efforts cannot succeed. In such a state, citizens use bribes to gain access to the state in order to meet their survival needs at the expense of others.

There is no country in which all requirements for a successful anticorruption effort can be fulfilled, but meeting a reasonable number of them is relevant for an effective anticorruption drive.

\section{THE STATE, NEOPATRIMONIALISM, AND ANTICORRUPTION EFFORTS}

The three elements discussed above are closely interlinked. The state is primarily established to pursue the ends of the governed such as providing for their welfare and security and administering justice. To do so, the state prescribes a system of laws and regulations, which includes an anticorruption framework. The citizens are only obligated to submit to the laws and authority of the state as long as the state is able to fulfill its core functions. To do so, the state and its representatives must be able to distance themselves from domestic or international class and ethnic interests, transcend or disregard clientelistic demands, and focus on their administrative functions. If the state fails in its capacity or fails to remain neutral, its legitimacy is likely to be questioned by its citizens, and they may develop parallel structures (neopatrimonial networks and 
logics) in order to survive.

However, because neopatrimonial strategies for protection and survival are not based on collective welfare, this reproduces insecurity and uncertainty in the politics and institutions of the state including its anticorruption efforts. The effective implementation of an anticorruption efforts requires institutions which, in the Weberian bent of modern states, should be impersonal in the application of law. State fragility begets neopatrimonial elements and can be linked with the prevalence of neopatrimonial characteristics. Both the weaknesses of the state and the logics of neopatrimonial actions are toxic to effective anticorruption efforts; the tonic is reinvention of the state and reconstruction of neopatrimonial values.

On the other hand, anticorruption efforts seek to defeat neopatrimonialism and build legitimacy for the state. This is because the anticorruption policy is based on the principles of accountability, transparency, efficiency, predictability, respect for institutions and laws, and formal interaction between stakeholders. Corruption threatens the legitimacy of the state and engenders unequal access to economic opportunities within it. Anticorruption efforts seek to reverse these situations.

\section{THE NIGERIAN STATE AND THE ANTICORRUPTION EFFORTS}

This section compares some distinctive aspects of the Nigerian state with the requirements for an effective anticorruption effort. An anticorruption effort must be politically neutral. The state is both an umpire and a stakeholder in Nigeria's economic and political processes; it is difficult, therefore, for it to provide the justice and equity required for an effective anticorruption effort. Nemo judex in causa sua (no one can be a judge in his own case).

In Nigeria, fear is widespread among stakeholders that the custodians of state power and authority could secure unfair advantage for themselves, their followers, and members of their party or homeland. In such an environment, anticorruption efforts are usually rationalized by those who are being prosecuted as an ethnic agenda or political witch-hunting so as to defeat its real purpose. This is well illustrated by the mixed reactions that greeted the removal and prosecution of the chief executives of some banks, most of whom were from the southern part of the country, by the Central Bank of Nigeria under the leadership of Mallam Sanusi Lamido Sanusi, a northerner, over allegations of corruption (Anya \& Amokeodo, 2010).

An anticorruption effort also requires sound institutions. In Nigeria, a number of anticorruption institutions and mechanisms have been established, including the criminal and penal codes, the Corrupt Practices Decree of 1975, the Ethical Code of Conduct of 
1979, the probe panels and military tribunals, the National Orientation Agency, Mass Mobilization for Social Justice, Self-Reliance and Economic Recovery, War Against Indiscipline and Corruption, Vision 2010, Money Laundering Act, privatization, monetization policy, high wage incentive and severance allowance for political office holders, Anti-corruption Act 2000, which led to the establishment of the Independent Corrupt Practices and Other Related Offences Commission, and Economic and Financial Crimes Commission (EFCC).

These institutions have been credited with several achievements. For example, between 1984 and 1985, the Special Military Tribunal on the Recovery of Public Property sentenced a number of principal actors for corrupt enrichment (Osaghae, 2002). In 2010, the EFCC said that it had in two years secured 100 convictions and recovered $\$ 3.5$ billion. High-profile personalities convicted included D. S. P. Alamieyeseigha, former Bayelsa State governor (now pardoned), Joshua Dariye, former Plateau State governor, and Tafa Blogun, former Inspector General of Police (Agbo, 2010). Yet, the anticorruption institutions do not inspire the confidence of many Nigerians. The integrity of anticorruption institutions in Nigeria such as the legislature, police, and the courts raises serious questions. These institutions have themselves been mired in, implicated for, and consumed by corruption (Osumah, 2012).

The legislative framework is the starting point in the fight against corruption; it provides the basis for identifying the elements of corruption to be investigated by the police and proven in a court of law. There have been allegations of widespread of corruption ranging from bribery, forgeries, and fisticuffs to appropriation impropriety in the legislature. Several members of the legislative leadership have been charged with corruption. Patricia Etteh, Speaker of the Federal House of Representatives, was deposed in 2007 on account of corruption. Salisu Buhari, Speaker of the Federal House of Representatives, and Evans Ewerem, Senate President, resigned after being charged with certificate forgery. Chuba Okadigbo was removed as Senate president. Members of the National Assembly were frequently bribed. In 2002, Senator Arthur Nzeribe acknowledged offering bribes of 3 million Nigerian naira to some members of the Senate to stop impeachment proceedings against President Olusegun Obasanjo for constitutional violations (Aghemelo \& Osumah, 2003; Akpe 2007; Omonjio, 2007; Osumah \& Ikelegbe, 2009; Utomi, 2004). A legislative committee set up to probe the power sector was accused of writing a report with the intent of jeopardizing the chances of some rivals for political office (Adekeye, 2008).

The Nigeria Police Force, which is responsible for investigating and prosecuting cases of corruption, lacks credibility and integrity and is known to be corrupt. Several police officers have been indicted. In 2005, the EFCC arraigned the former Inspector General of Police, Tafa Balogun, on 70 counts including stealing and money laundering 
over N18 billion (Nwokocha, 2005). The Nigeria police are not only corrupt but also lack investigation skills. Hence, there has been a loss of confidence in the policing system.

Some military personnel who took part in an anticorruption drive during the administration of General Mohammadu Buhari were accused of helping themselves to some of the money recovered from civilian officials apprehended for corruption. For example, in Kano state, the governor, Sani Barkin Zuwo, was arrested by the military, and a large amount of government funds were found in his official residence; he later said publicly that the military found much more money in his residence than they disclosed (Szeftel, 2000a).

Equally, the educational institutions statutorily charged with the responsibilities of setting the agenda for the discourse of positive and moral values have been disappointing. Non-salutary, unsavory and unrespectable deployment of any means possible by professors in Nigerian universities in order to secure the seat of vice chancellor or another executive position have been commonplace in the higher educational institutions. Other ills include sales of honorary degrees, admission racketeering, selling of grades, and widespread allegations of sexual harassment by lecturers or sexual enticement by students (Igbinovia \& Aigbovo, 2009; Okecha, 2008; Agbaegbu, 2010; Enogholase, 2012). The civil service has been characterized by bribery, nepotism, tribalism, increasing list and prices of items purchased, inflation of contract sums, using of official time for private business, absenteeism, and "ghost" workers (Igbinovia \& Aigbovo, 2009; Osumah, 2012). The institutions on which Nigeria must rely to carry out anticorruption efforts are fragile.

Corruption has also been exposed within the Nigerian judicial system, especially where big-time offenders are involved. A number of court officers have been accused of taking bribes. For instance, the Derivation Front, a civil society group petitioned the Supreme Court over allegations that two justices of the High Court had taken bribes in the 2003 general election case regarding Chief James Ibori, a former Delta State governor. Some judges have been sacked over allegations of compromise or sale of justice. Also, the former chair of the EFCC, Farida Waziri, accused the judiciary of frustrating the efforts of the commission to combat corruption on account of legal technicalities or black market (inappropriate) court injunction (Agbo, 2010). Since 2008, Peter Odili, former Rivers State governor, obtained a perpetual injunction to stall his investigation and trial on charges of corruption allegedly committed while in office, which is yet to be vacated (Implications of Okah's conviction, 2013).

A further testament to the perverted nature of the criminal justice system is the conviction of Ibori by the Southwark Crown Court in the United Kingdom on charges of money laundering and corrupt enrichment of over $\$ 250$ million. Ibori had earlier 
been acquitted by a High Court in Warri, Delta State. He was cleared by the Nigerian judicial system of charges of having been convicted, despite the abundance of evidence, including the testimony of the judge who jailed him. In addition to Ibori's case is the conviction in South Africa of Henry Okah, a former militant leader in the Niger Delta, for acts of terrorism committed in Nigeria (Implications of Okah's conviction, 2013).

Numerous companies in Nigeria have obtained contracts through bribes. While in their home countries, officials of Siemens, Halliburton, and Panalpina, among others, have been fined heavily, their accomplices in Nigeria are free (Implications of Okah's conviction, 2013). How were the judicial systems in other countries such as the United Kingdom and South Africa able to achieve that which the Nigerian judicial system, which has its roots in British common law, could not?

Deterrence is a critical aspect of an effective anticorruption effort. As Declan (2008, p. 141) noted, "Jail terms and/or fines commensurate with the degree of offence combine to strengthen deterrent effect." In Hong Kong, Singapore, and Botswana, known for their successful anticorruption reforms, success is attributed partly to the imposition of sanctions such as imprisonment, confiscation of assets, fines, and prohibition from future employment (Drielsma, 2000).

In Nigeria, the anticorruption efforts have essentially been based on a manner favoring high-profile personalities rather than the ordinary citizens (Paden, 2004). Ordinary citizens have often received longer prison sentences than high-profile personalities who stole a great deal more. For example, Bode George, former chairman of Nigeria Ports Authority and national vice chairman of the People's Democratic Party, was sentenced to a two-year term for corruption involving $\$ 100$ billion, while private citizen Christopher Chukwu was sentenced to a 13-year term for impersonation and stealing of 1.5 million. Ordinary citizens Ajani Ajawesola and Adewale Alexander were sentenced to 24 years in prison for obtaining million under false pretenses, while Lucky Igbinedion, former Edo State governor, paid only a paltry fine of 3.5 million for corruption of more than 4.3 billion (Agbo, 2010).

Equally toxic to the effectiveness of anticorruption efforts is the rentier character of the Nigerian state. The centrality of oil to the rentier state's capacity reproduces its brand of patrimonialism and patronage (Obi, 2002; Omeje, 2006). In Nigeria, the emergence of oil rents as the dominant source of revenue resulted in wasteful spending and execution of ambitious projects hampered by corruption and rent-seeking under the military regimes of Generals Yakubu Gowon, Murtala Mohammed, Olusegun Obasanjo, Ibrahim Babangida, and Sani Abacha. For instance, corruption hampered the industrial initiatives in metallurgy, petrochemicals, automobiles, pulp, and paper (Lewis, 2004). Moreover, it can be argued that the rentier character of the Nigerian state accounts for the inability of past leaders to account for over $\$ 400$ billion in oil 
money since independence (Ikubaje, 2006). This rentier character increases the opportunity for rent seeking and a perception of the state as a "national cake" to be shared.

Anticorruption efforts require the participation of all stakeholders. The Nigerian state, as a state controlled by cabal, fails to encourage productive investment by all stakeholders. This creates incentives for only a few to rally support for a common cause, and it cannot elicit the co-operation of the neglected majority of citizens. Even the few individuals who benefit from the state are divided and more concerned with rent seeking than with productive investment (Otite, 2007). On the other hand, the majority of the citizenry who are excluded and neglected have grown apathetic about affairs of the state. At best they rally support for those who benefit through corruption in order to secure meager rents for survival (Okumu, 2002).

The economic viability of the state is also a critical variable in the effective administration of anticorruption law. The success of anticorruption reform in Botswana, which is celebrated as Africa's best example, is attributed partly to sound economic policy and development (Drielsma, 2000). Though the Nigerian state is richly endowed with human and material resources, it ranks low in standard economic indexes. Because of the weak economic base, the political actors engage in avaricious rent seeking rather than productive accumulation. The abundance of resources exacerbates this tendency and elevates the scale of corruption. Also, the nature of economic reform recommended by international financial institutions condemns corruption and imposes sanctions on corrupt government, the punishment hardly influences the individuals or factions involved in corruption, who are offered vast fortunes by multinational companies or drug dealers. In addition, reforms such as structural adjustment, liberalization, and even democratization considerably undermine the regulatory capacity of the state by stripping it of oversight capabilities. With increasing withdrawal of the state from the financing of various activities, there is the likelihood that auditing, investigation, and enforcement will be seriously threatened.

The ideology of rolling back the state, and the policies of deregulation and privatization if anything reduced the capacity of government to regulate corruption rather than reducing the corruption itself. ... There is little in the reforms being espoused by the donors that seem equipped to break the circle and begin a process of renewal. If anything their strategy seems likely to exacerbate corruption and so undermine the important changes they wish to implement. (Szeftel, 2000b, p. 439) 


\section{NEOPATRIMONIALISM AND THE ANTICORRUPTION EFFORTS}

This section explores the implications of neopatrimonialism for the anticorruption efforts. One of the requirements for an effective anticorruption effort is the provision of opportunities, recognition, and protection for whistle-blowers. In Hong Kong, which mounted a successful anticorruption drive through the Independent Commission Against Corruption, recognition and protection of whistle-blowers was crucial. In 19741975, the Commission received 6,368 complaints, possibly because of the guarantee of protection for whistle-blowers (Drielsma, 2000). Such a high number of reports may not possible in a neopatrimonial system characterized by personal rule and a tendency toward kabieyeism (monarchical conception and exercise of power). By personalized rule, the custodians of state power see their positions as an opportunity to enrich themselves, develop personal loyalties, and use private armies as the chief instruments of rule (Willame, 1972). Ivory Coast under Boigny, Central African Republic under Bokassa, Zaire under Mobutu, and Togo under Eyadema are examples of personalized rule that accorded whistle-blowers little opportunity, recognition, or protection.

In Nigeria, political leadership is often personalized and offers little opportunity, recognition, or protection for whistle-blowers. Successive administrations, military and civilian, punished their critics and opponents. For example, the then editor-inchief of The Spark, Obarogie Ohanbamu, was jailed over a story about Murtala Mohammed's ownership of houses in Kano, and he was not released until after the death of Murtala (Nwabuzor, 2003). Also, Vincent Azie, then Auditor-General of Nigeria, was sacked following his submission of an annual report in December 2001 which indicated that the three arms of government were culpable of financial misdeeds including over-invoicing, payment for jobs not executed, release of funds without approval, and nonretirement of cash invoices (Aghemelo \& Osumah, 2003; Akpotor 2003). Former EFCC chairman, Mallam Ribadu, was deposed after indicting highprofile politicians for corruption; he was subsequently demoted and fired by the Nigeria Police Service Commission, but was reinstated and retired after the death of former President Alhaji Umaru Musa Yar'Adua.

Neopatrimonialism also diminishes another requirement of anticorruption effectiveness, public integrity and trust. It impairs the political will required to develop, enhance, and sustain the strong measures needed to identify and eliminate corrupt values and behavior. In Nigeria, like most other African states, political leaders are venal, self-indulgent, greedy, and driven by an appetite for an ostentatious life-style, which in common parlance is known as the big man syndrome (Declan, 2008). For instance, General Babangida, who ruled Nigeria for eight years, according to Diamond (1995), was obsessed with his own wealth, power, and glory, constantly manipulating 
the self-interests and divisions among politicians to remain in office. The political values and expectations of Babangida's own cynical and corrupt style of governance led him to continually shuffle appointments and dole out cash, contracts, and lucrative postings to solidify his grip on power. Similarly, driven by an appetite for wealth, sadistic egotism, and political ambition, Abacha ran the Nigerian treasury and economy like a personal estate, and to protect the estate, the political fortunes of the nation had to be subordinated to his whim. He used money taken directly from the Nigerian Central Bank (Diamond, 1995).

In the civilian administration between 1999 and 2007, Olusegun Obasanjo, who was president, and his vice president, Atiku Abubakar, were alleged to have granted themselves licenses to operate private universities. A much more potent demonstration of a cynical style of governance and neopatrimonial intent and posturing by Obasanjo was his alleged used of his position as president to raise funds from governors, other political officeholders, and leading chief executives in the private sector. He was also alleged to have attempted to bribe the National Assembly with a huge sum of money in his bid to secure a third term in office (Osumah, 2012).

The big man syndrome is not limited to one African state. Bayart (1993) observed that it has been disastrous for the continent. The inordinate concern for personal interests, and selective favoring and rewarding of supporters, as evidenced in the neopatrimonial system, threatens integrity and contributes to the entrenchment of a culture of impunity and protection of the image of culpable but wealthy individuals. This is reflected in the non-implementation of several reports on corruption such as Justice Bergore's report on the bottlenecks in Nigerian ports over the armada (undetermined quantities) of cement import involving top military officials in the Obasanjo military administration, and the late Pius Okigbo's panel of inquiry on the transfer of $\$ 12$ billion from the Central Bank of Nigeria to a dedicated account directly under President Babangida (Nwabuzor, 2003).

It has been contended that the investigation of the Halliburton bribery scandal involving \$180 million has remained inconclusive because of lack of political will to prosecute the people involved in the deal. Some of the top political figures that allegedly shared in the deal include some former heads of state (November 17, 1993-May 29, 2007), some ex-Petroleum Ministers, and relatives of some prominent traditional rulers in the country (Mbamalu 2010). There is no doubt that these prominent figures, through personality cults and perpetuation of outrages with impunity, encourage corruption and are thus toxic to anti-corruption efforts.

Effective anticorruption efforts emphasize the rule of law, which repudiates discrimination based on class, religion, or political or ethnic affiliation. This is inconsistent with the neopatrimonial system, which is based on personal relations, family ties, 
communalism, clientelism, friendship, and gift-giving. Hindsight reveals the breach of political neutrality due to pressure from proximate constituencies.

For example, the investigation of the principal actors of the Second Republic (civil rule between October 1, 1979 and December 31, 1983) for corruption was believed to be selective. Although ex-governor Solomon Lar had a case of corruption that was similar to ex-governor Goni of Bornu State, it was not clear why the former was sentenced to a long prison term and the latter was discharged and acquitted. Also, it was not clear why the National Party of Nigeria and northern politicians such as Barkin Zuwo, Garba Nadama, and Abubakar Rimi received less punishment than nonNational Party of Nigeria and southern politicians such as Ambrose Folorunso Alli and Sam Mbakwe - or why President Alhaji Shehu Shagari, a northerner, was placed on a house arrest and his vice president, Alex Ekwueme, a Southerner, was detained in the prison (Osaghae, 2002, p. 175).

In this current democratic dispensation (civil rule restored since May 1999), the EFCC has been accused of maintaining a double standard and of selectiveness in the prosecution of suspected treasury pilferers. For example, two former state governors, Alhaji Attahiru Bafarawa of Sokoto State and Alhaji Abdullahi Adamu of Nassarawa State, who were alleged to have embezzled their states' finances in the amount of N15 billion each, were prosecuted differently. Bafarawa was an All Nigerian People's Party governor before joining the Democratic People's Party, while Adamu was a People's Democratic Party governor and later a secretary of its board of trustees. The EFCC arraigned Bafarawa before a State High Court in Sokoto on charge of embezzlement of public funds and corruption, while Adamu was arraigned before a Federal High Court in Lafia, Nassarawa State (Farouk, 2010). In addition, during the Obasanjo presidency, the Independent Corrupt Practices Commission and the EFCC were regarded as instruments of political witch-hunts, blackmail, and vendetta (Aghemelo \& Osumah, 2003; Osumah \& Ikelegbe, 2009).

Neopatrimonialism revolves around personalized relationships, while anticorruption efforts require a rational-legal framework. In Nigeria, evidence abounds of the crippling effects of personal relations on anticorruption efforts. For example, it was alleged that the personal ties between President Yar'Adua and Ibori insulated Ibori from sanctions for the series of financial crimes he was accused of both at home and abroad before his arrest and deportation from Dubai to the United Kingdom. The grounds for suspicion include the following: Ibori was one of the closest friends of Yar'Adua. Both were state governors (in Kastina and Delta States, respectively) between 1999 and 2007. Ibori was also alleged to be the chief financier of Yar'Adua's election in 2007 (Bamidele, 2009).

The influence of a patron-client network also underscored the alleged efforts of 
Michael Aondoakaa, as minister of Justice and Attorney-General, to shield Ibori from prosecution. Ibori was allegedly instrumental in his appointment. Perhaps as a way to settle his political debt, on September 10, 2009, Aondoakaa was reported to have stated that the EFCC had cleared Ibori and two other former governors, Architect Victor Attah of Akwa Ibom State and Alhaji Asiwaju Bola Ahmed Tinubu of Lagos State, of charges relating to their alleged sales of their states' shares in Econet Wireless Network, though the commission had not concluded its investigation. Also, Aondoakaa allegedly claimed it was Nuhu Ribadu as former EFCC chairman who rekindled the interest of the British in the money laundering case against Ibori in a bid to embarrass Nigeria. Still, he allegedly held that the federal government of Nigeria would not approve the request of the London Metropolitan Police to extradite Ibori for trial in Britain on charges of money laundering of about $\$ 140$ million (Bamidele, 2009).

Additional evidence of the influence of neopatrimonialism on anticorruption efforts is the state pardon of Alamieyeseigha, who was convicted of money laundering and sentenced to a two-year prison term, by President Goodluck Jonathan. Jonathan had described Alamieyeseigha as his political benefactor and mentor. The approval of the state pardon was perhaps intended to settle his political debt (Jonathan's unforgivable state pardon, 2013).

Effective anticorruption efforts emphasize elevation of the national interest above narrow and parochial interests by all citizens. In Singapore, where corruption was rife due to weak laws and lack of public education on corruption, the success of its anticorruption agency, the Corrupt Practice Investigation Bureau, was informed by public commitment through demonstrations demanding anticorruption efforts (Drielsma, 2000). However, in Nigeria as in most African states, ethnic and linguistic factionalization have been found to be associated with the pattern of behavior of many peasants, creating a social barrier that precludes their organizing to advance their interests (Declan, 2008). Such particularistic attachments play a crucial role in the attitudes, behaviors, and values of individuals in the society. Neopatrimonialism defeats efforts to address public needs and promote moral excellence, ethics, and accountability, and encourages factionalism, nepotism, schism, and parochialism, which inhibit anticorruption efforts. As retired Chief Justice Dahiru Musdapher at a lecture and book presentation on December 20, 2012 in Lagos noted:

Our capacity to investigate, arrest, prosecute and convict those found guilty of contravening our laws is evidently weak and compromised ... if a person is accused of wrong-doing in Nigeria, his kinsmen are quick to relate his clear transgressions to some kind of conspiracy against their own. Corruption and nepotism is supported and encouraged by its benefactors at the expense of all others (Vanguard News, 2013, p.13). 
An illustration of this clientelistic disposition is the agitation by various stakeholders in Nigeria to ensure that a kinsman gets the presidential slot on the ticket of the ruling People's Democratic Party, in the expectation that when their kinsman is president he will corruptly use the position in the advantage of his homeland. Candidates for other offices are supported with the same expectations. For example, the kinsmen of Bode George supported him during his trial at the High Court in Lagos. And the people of Bayelsa State protested the arrest of Alamieyeseigha, interpreted it as an orchestration of the Federal Government, and celebrated his escape from police custody in London in 2006 and return to Nigeria. Militant youth in Oghara allegedly offered armed resistance to an attempt by the EFFC to arrest Ibori over corruption (EFCC vs. Ibori, 2010; Obijiofor 2010).

Neopatrimonial networks have thwarted anticorruption efforts in a number of countries in addition to Nigeria, including Malawi, Tanzania, Swaziland, India, and Cameroon. In India, like in Nigeria, there are a number of anticorruption mechanisms but yet there is no considerable improvement of public integrity due to neopatrimoni-

Table 1. Transparency International Corruption Perception Index for Nigeria and Selected Other Countries, 2006-2010

\begin{tabular}{l|r|r|r|r|r}
\hline \multicolumn{1}{c|}{ Country } & 2006 & 2007 & 2008 & 2009 & 2010 \\
\hline Botswana & 37 & 38 & 36 & 37 & 33 \\
\hline Hong Kong & 16 & 14 & 12 & 12 & 13 \\
\hline Singapore & 5 & 4 & 4 & 3 & 1 \\
\hline Cameroon & 138 & 138 & 141 & 146 & 146 \\
\hline India & 70 & 72 & 85 & 84 & 87 \\
\hline Malawi & 105 & 118 & 115 & 89 & 85 \\
\hline Nigeria & 142 & 147 & 121 & $\mathbf{1 3 0}$ & $\mathbf{1 3 4}$ \\
\hline Swaziland & 121 & 84 & 72 & 79 & 91 \\
\hline Tanzania & 93 & 94 & 102 & 126 & 116 \\
\hline Afghanistan & $\mathrm{NR}$ & 172 & 176 & 179 & 176 \\
\hline Burundi & 130 & 131 & 158 & 168 & 170 \\
\hline Haiti & 163 & 177 & 177 & 168 & 146 \\
\hline Sierra Leone & 142 & 150 & 158 & 146 & 134 \\
\hline Somalia & $\mathrm{NR}$ & 179 & 180 & 180 & 178 \\
\hline Total number of countries ranked & 163 & 179 & 180 & 180 & 178 \\
\hline
\end{tabular}

Sources: reports of Transparency International Corruption Index cited in Osumah (2012) Note: NR: Not Ranked 
alism (Lodha, 2007). In Tanzania and Cameroon, clientelistic links among the elites have undermined anticorruption drives. In Malawi and Swaziland, like in Nigeria, anticorruption agencies have not been able to investigate and successfully prosecute high-profile cases because of institutional weakness (Drielsma, 2000).

Countries like Nigeria, Cameroun, Malawi, Swaziland, Tanzania, and India, in which political behaviors and attitudes were heavily influenced by neopatrimonialism, have ranked lower in the Transparency International Corruption Perception Index (table 1); so have countries characterized as fragile states, such as Nigeria, Burundi, Afghanistan, Sierra Leone, Haiti, and Somalia. The World Bank (2006) noted that fragile states are characterized by significant corruption, breakdown of the rule of law, absence of mechanisms for generating legitimate power and authority, and weak policies and institutions. Each of these characteristics is well represented in Nigeria.

Within the period reflected in this table, Singapore, Hong Kong, and Botswana, known for the effectiveness of their anticorruption efforts, consistently ranked far better than countries like Nigeria, Cameroon, Swaziland, Malawi, and India, which have been characterized as deeply neopatrimonial in their political attitudes and actions. Among the countries highly disposed to neopatrimonialism, Nigeria ranked lowest, except for Cameroon in 2008, 2009, and 2010. Among fragile states, in 2006, Nigeria shared a rank (142nd) with Sierra Leone and was only marginally ahead of Haiti. In 2007, Nigeria ranked 147th, ahead of Afghanistan, Haiti, and Sierra Leone. In 2008 (121st) and 2009 (130th), Nigeria ranked marginally ahead of other fragile states (Haiti, Afghanistan, Burundi, and Sierra Leone). In 2010, Nigeria shared the 134th position with Sierra Leone but did somewhat better than Haiti, Afghanistan, and Burundi.

\section{CONCLUSION: FROM TOXIN TO TONIC}

Anticorruption reform efforts in virtually every country are necessitated by the need to combat corruption and its catastrophic consequences. Thus, the initiation of anticorruption efforts rekindles hope of improvement in a society where the problem of corruption has been widespread. There is, however, variety in the motivations for and approaches to anticorruption reform. While some countries' anticorruption efforts have yielded results, those of some others have yet to make a significant impact, for various reasons.

Dysfunctional elements of the Nigerian state as well as widespread neopatrimonialism defeat the objectives of the anticorruption efforts. These trends are not peculiar to Nigeria: India, Cameroon, Tanzania, and Swaziland have had similar experiences. Nigeria's anticorruption effort lacks attributes—such as high-level political commitment, 
popular support, and strong legal and institutional mechanisms - that have aided the more successful anticorruption efforts in countries such as Hong Kong, Singapore, and Botswana.

Reconstruction of elements of the Nigerian state is essential to limit its encouragement of corrupt behavior and hindrance of anticorruption efforts and institutions. There is no perfect institution anywhere; each system has its positive and negative aspects. Thus, in addition, to the reinvention of the state, there is a need for the rejuvenation of the value system to remove neopatrimonial influence on political interactions through personal rule, patronage, and clientelism.

\section{REFERENCES}

Adekeye, F. 2008, August 25. Contractors fight back. Tell, pp. 20-30.

Agbaegbu, T. 2010, May 3. Three Abia Varsity Officials in Trouble. Newswatch, pp. 20-22. Agbo, A. 2010, June 28. How the judiciary aids corruption. Tell, pp. 16-23.

Aghemelo, A. T., \& Osumah, O. 2003. Governance and the challenges of poverty and corruption in Nigeria. In F. E. Iyoha, V. O. Aghayere, \& P. O. Oviasuyi (eds.), Rethinking governance and development in the 21st century (pp. 378-387). Ekpoma, Nigeria: Institute for Governance and Development.

Aghemelo, A.T \& Osumah, O. 2009. Nigerian government and politics: An introductory perspective. Benin City: Mara Mon Bros \& Ventures Limited.

Akpe, S. 2007, October 4. Madam speaker, my frank suggestion is that ... Daily Independent, pp. A12.

Akpotor, A. S. 2003. Good governance and the accountability question. In F. E. Iyoha, V. O. Aghayere, \& P. O. Oviasuyi (eds.), Rethinking governance and development in the 21st century (pp. 175-186). Ekpoma, Nigeria: Institute for Governance and Development.

Anya, E., \& Amokeodo, T. 2010, April 28. EFCC recovers $\$ 6$ bn from ex-govs, others. The Punch, pp. $1 \& 2$.

Awolowo, O. 1947. Path to Nigerian freedom. London: Faber and Faber limited.

Awolowo, O. 1968. The people's republic. Ibadan: Oup.

Bamidele, J. 2009, October 12. The new godfather. The News, pp. 16-21.

Bayart, J. F. 1993. The state in Africa: The politics of the belly. London: Longman.

Bello-Imam, I. B. 2005. The war against corruption in Nigeria: Problems and prospects. Ibadan, Nigeria: College Press \& Publishers.

Boas, M. 2001. Liberia and Sierra-Leone: Dead ringers? The logic of neopatrimonial rule. Third World Quarterly, 22(5): 697-723. 
Bratton, M., \& Van de Walle, N. 1997. Democratic experiments in Africa. Cambridge: Cambridge University Press.

Callaghy, T. 1987. The state as lame leviathan: The patrimonial administrative state in Africa. In Z. Ergas (ed.), African state in transition (pp. 87-116). New York: Martin's Press.

Chabal, P. and Daloz, J.P. 1999. Africa works: Disorder as political instrument. Oxford: James Currey for the International African Institute.

Coleman, J. S. 1958. Nigeria: background to nationalism. Benin City: Broburg Wistrom.

Declan, A. A. 2008. Anticorruption in Africa: The cases of Ghana and Nigeria. Doctoral thesis, Durham University, Durham, UK.

deGrassi, A. 2008. Neo-patrimonialism and agricultural development in Africa: Contributions and limitations of a contested concept. African Studies Review, 51(3): 107-133.

De Oliveira, R. S. 2007. Oil and politics in the Gulf of Guinea. London: Hurst.

Dia, M. 1996, Africa's management in the 1990s and beyond: Reconciling indigenous and transplanted institutions. Washington, DC: World Bank.

Diamond, L. 1995. Nigeria: The uncivic society and the descent into praetorianism. In L. Diamond, Juan J. Linz \& Seymour Martins Lipset. (eds.), Politics in developing countries: Comparing experiences with democracy (2nd ed.) (pp. 416-491). London: Lynne Rienner.

Drielsma, C. H. 2000. Successful anti-corruption strategies around the globe: A report for lok satta completet d, Botswana's DCEC "supercow."

EFCC vs. Ibori: The rule of law on trial. 2010, April 23. Daily Independent, p. 31.

Ekeh, P. P. 1975. Colonialism and two publics in Africa: A theoretical statement. Comparative Studies in Society and History, 17(1): 91-121.

Enogholase, G. I. 2012, March 3. FG frowns at lopsided recruitment in UNIBEN. Vanguard, p. 9.

Erdmann, G., \& Engel, U. 2006. Neo-patrimonialism revisited-Beyond a catch-all concept. Legitimacy and Efficiency of Political Systems, GIGA Working Paper No. 16. Retrieved October 16, 2009, from www.giga-hamburg.de/workingpapers.

Erdman, G., \& Engel, U. 2007. Neo-patrimonialism reconsidered: Critical review and elaboration of an elusive concept. Commonwealth \& Comparative Politics, 45(1): 95-119.

Farouk, I. 2010, March 12. EFCC and the politics of Bafarawa's trial. The Nation, p. 18.

Goodling, N. A. 2003. Nigeria's crisis of corruption-Can the UN global programme hope to resolve this dilemma? Vanderbilt Journal of Transnational Law, 36 (3): 997-1026.

Hansen, K. F. 2003. The politics of personal relations: Beyond neo-patrimonial practices 
in northern Cameroun. Africa, 73(2): 202-225.

Held, D. 1992. The development of the modern state. In S. Hall \& B. Gieben (eds.), Formation of modernity (pp. 71-117). Oxford: Polity Press.

Igbinovia, P. E. and Aigbovo, O. 2009. Corruption: A Bane to Efficiency and Effectiveness in the Public Service In V.O. Aghayere and F.E. Iyoha (eds.) Ethics, Standard and Accountability in Governance (pp. 43-55). Benin City: Imprint Services.

Ihonvbere, J. O. 1994. The "irrelevant" state, ethnicity and quest for nationhood in Africa. Ethnic and Racial Studies, 17(1): 42-60.

Ikubaje, J. 2006. Corruption and anti-corruption in Nigeria. Lagos: Joe-Tolalu \& Associates.

Implications of Okah's conviction in South Africa. 2013, February 10. The Punch, p. 16.

Jackson, R. H., \& Rosberg, R. I. 1982. Why Africa's weak states persist: The empirical and the juridical in statehood. World Politics, 35(1): 1-24.

Jonathan's unforgivable state pardon. 2013, March 17. The Punch, pp. $1 \& 16$.

Joseph, R. 1987. Democracy and prebendal politics in Nigeria. Cambridge: Cambridge University Press.

Joseph, R. 1995. November. The dismal tunnel: From prebendal state to rogue state in Nigeria. Paper presented at the conference on the dilemmas of democracy in Nigeria, University of Wisconsin-Madson, November 10-12.

Lewis, P. 2004. Getting the politics right: Governance and economic failure in Nigeria. In R. I. Rotberg (ed.), Crafting the new Nigeria: Confronting the new challenges (pp. 99-124). Boulder, CO: Lynne Rienner.

Lodha, S. 2007. Fighting corruption: A comparative study of civil society initiatives for securing freedom of information in Nigeria and India. Madhya Pradesh Journal of Social Sciences, 12(2):1-21.

Mamdani, M. 1996. Citizen and subject: Contemporary Africa and the legacy of late colonialism. London: James Currey.

Mbamalu, M. 2010, May 9. Halliburton: Open sore of a nation. The Guardian, p. 10.

Nwabuzor, E. J. O. 2003. Corruption and democracy: The Nigerian case. In F. E. Iyoha, V. O. Aghayere, \& P. O. Oviasuyi (eds.), Rethinking governance and development in the 21st century (pp. 242-278). Ekpoma, Nigeria: Institute for Governance and Development.

Nwokocha, J. 2005, November 27. Balogun: The super cop falls. Vanguard, p. 12.

Obi, C. I. 2002. Oil and the minority question. In A. Momoh \& S. Adejumobi (eds.), The national question in Nigeria: Comparative perspectives (pp. 97-118). Famham, Surrey, United Kingdom: Ashgate Publishing.

Obijiofor, L. 2010, April 30. Ibori: In hiding a clear conscience. The Guardian, p. 10. 
Ogbeide, U. E. 2003. Peasants, the state and rural development in Nigeria: A radical approach. In F. E. Iyoha, V. O. Aghayere, \& P. O. Oviasuyi (eds.), Rethinking governance and development in the 21st century (pp. 187-206). Ekpoma, Nigeria: Institute for Governance and Development.

Ogundiya, I. S. 2009. Political corruption in Nigeria: Theoretical perspectives and some explanations. Anthropologist, 11(4): 281-292.

Ojo, S. O. J. 1995. Applying the structural adjustment programme to the Nigerian polity. In F. E. Iyoha, B. U. Chizea, \& S. A. Akpotor (eds.), Self-reliance, politics and administration in Nigeria (pp. 49-73). Benin City, Nigeria: Imprint Services.

Okecha, A. S. 2008, October 6. Education. Newswatch, pp. 21-24.

Okumu, W. A. J. 2002. The African renaissance, history, significance and strategy. Asmara, Eritrea: Africa World Press.

Omeje, K. 2006. The rentier state: Oil-related legislation and conflict in the Niger delta, Nigeria. Conflict, Security and Development, 6(2): 211-230.

Omonijo, B. 2007, October 19. Etteh: As Integrity and Ettehgrity groups claim first casualty. Vanguard, p. 19.

Osaghae, E. E. 2002. Crippled giant: Nigeria since independence. Ibadan, Nigeria: John Archer.

Osaghae, E. E. 2007. Fragile state. Development in Practice, 17(4-5): 691-699.

Osumah, O. 2012. Corruption complex and anti-corruption policy effectiveness in Nigeria, 1999-2010. Doctoral thesis, University of Benin, Benin City, Nigeria.

Osumah, O., \& Ikelegbe, A. O. 2009. The Peoples Democratic Party and governance in Nigeria, 1999-2007. Journal of Social Sciences, 19(3): 185-199.

Otite, O. 2007. The Nigerian power elite and unity. In E. E. Osaghae and E. Onwudiwe (eds.), The management of the national question in Nigeria (pp. 73-82). Okada, Nigeria: Igbinedion University Press.

Paden, J. R. 2004. Unity with diversity: Toward democratic federalism. In R. I. Rotberg (ed.), Crafting the new Nigeria: Confronting the new challenges (pp. 17-37). Boulder, CO: Lynne Rienner.

Reno, W. 2000. Shadow state and the political economy of civil wars. In D. M. Malone \& M. R. Bredal (eds.), Greed and grievance: Economic agendas in civil wars (pp. 43-68). Boulder, CO: Lynne Rienner.

Rose-Ackerman, S. 1999. Corruption and government: Causes, consequences and reform. Cambridge: Cambridge University Press.

Rotberg, R. I. 2004. Troubled Nigeria: Great opportunities, tough challenges. In R. I. Rotberg (ed.), Crafting the new Nigeria: Confronting the new challenges (pp. 1-16). Boulder, CO: Lynne Rienner.

Smith, D. J. 2007. A culture of corruption: Everyday deception and popular discontent 
in Nigeria. New Jersey: Princeton University Press.

Stouffer, W. B., Opheim, G. , \& Day, S. B. 1996. State and local politics: The individual and the governments. New York: HarperCollins College Publishers.

Szeftel, M. 2000a. Between governance and underdevelopment: Accumulation and Africa's “catastrophic corruption." Review of African Political Economy, 27(84): 287-306.

Szeftel, M. 2000b. Clientelism, corruption and catastrophe. Review of Africa Political Economy, 27(85): 427-441.

Turok, B. 1987. Africa: What can be done. London: Zeb Books.

UNODC (United Nations Office on Drugs and Crime). 2003, November. UN guide for anticorruption policies. New York: Author.

Utomi, P. 2004. Nigeria as an economic powerhouse: Can it be achieved? In R. I. Rotberg (ed.), Crafting the new Nigeria: Confronting the new challenges (pp. 125-137). Boulder, CO: Lynne Rienner.

Van De Walle, N. 2001. African economies and the politics of permanent crisis, 19791999. Cambridge: Cambridge University Press.

Vanguard News. 2013, December 21. Boko Haram insurgency, signal of failed stateMusdapher. Vanguard, p. 13.

Willame, J. C. 1972. Patrimonialism and Political Change in the Congo. Stanford, CA: Stanford University Press.

World Bank. 2006. Engaging with fragile states: An lEG review of World Bank support to low-income countries under stress. Washington DC: World Bank.

Wunsch, J. S., \& Olowu, D. 1995. The failure of the centralized African state. In J. S Wunsch \& D. Olowu, (eds.), The failure of the centralized African State: Institutions and self-governance in Africa (pp. 1-22). U.S.A: ICS Press.

Zartman, I. W. 1995. Collapsed states, the disintegration and restoration of legitimate authority. Boulder, CO: Lynne Rienner. 